\title{
New Literacy for Reading Using ICT
}

\section{Rosabel Roig-Vila ${ }^{1}$ - Santiago Mengual-Andrés ${ }^{2}$}

${ }^{1}$ University of Alicante

${ }^{2}$ University of Valencia

doi: 10.7358/ecps-2014-010-roig

Rosabel.roig@ua.es

Santiago.mengual@uv.es

L'USO DELLE TIC PER UNA NUOVA ALFABETIZZAZIONE NELLA LETTURA

\section{Abstract}

This article will analyse the key strategies in the relationship between reading and writing in the area of ICT and the resulting importance in supporting literacy in this area so that the education system as a whole (primary and secondary schools and universities) can be guided to make full use of the opportunities ICT can provide. ICTs are able to help improve overall comprehension, evaluate general perspectives and raise awareness of the value of cooperation and, as a result, the essential quality of individuals and their contributions. These contributions are far-reaching and strategic. The benefits of applying ICT in reading and writing are also felt in oral expression and can result in education based more on dialogue which, in turn, leads to social change.

Keywords: Didactics of reading and writing, Digital identity, History of culture, ICT, School organisation.

\section{READING AS A COMPONENT OF A NEW CULTURAL MODEL}

"Culture», in its broadest sense, covers everything that human beings are capable of creating, but is not in itself part of the nature of those beings. Culture is designed and maintained socially through a symbolic system which is part of the heritage of different groups of human beings. Despite this, or arguably as a result of this, society has generated ideas which have resulted 
in technological advances designed to establish themselves and result in progress (Watson, 2010).

Electronic and printed media have produced an avalanche in the quantity of information that reaches us on a daily basis. Information is a raw material of crucial importance which is produced, reprocessed, transformed and sold in the same way as any other "more or less» manufactured product. Information and interest in it have not only penetrated deep into official bodies, agencies, organisations and other public and private entities, but also into practically every facet of everyday life. The consumption, handling and manipulation (whether more or less out of self-interest) and the use, transmission and production of information are normal events, habitual even, and are often carried out without us even realising. In fact, we can even say that it depends on a significant part of the person's social condition or - without putting it too pompously - culture itself. This is closely linked to the development of alphabets (and literacy), writing (documents) and different types and formats, the history of which are closely related to the evolution of civilisation, in general, and linguistic thought (and science), in particular (Tusón, 2012). It is also linked to the development of literature (both fiction and non-fiction), the didactics of language and literature, and more specifically the virtuality mimesis for improving the learning of complex language skills (Tusón, 2013; López Poza \& Pena Sueiro, 2014).

As a result, the concept of culture and even of education is redefined. As we have seen, each important technical revolution has been closely and intensely related to progress in society and culture as a whole (the change from clay tablets to papyrus, from papyrus to parchment, from parchment to paper and then onto virtual/digital formats; from rolls to codices/books, from manuscripts to printing and then onto hypertext) - at least with regard to how they have contributed to the processing, storage, transmission, handling and production of information. However, in modern society, the sheer volume of information, continuous advances or progress in science and technology, new possibilities (or impulses) in business or simply expression, mass distribution of information and data transmission and audiovisual communications media across all social and economic strata constitute a whole, or a more or less structured jumble of new information channels which can be used to actually transmit the information while it is still being processed or even created. 


\section{ICT AND INSTANT, OMNIPRESENT, ALL-EMBRACING AND ETERNAL READING AND WRITING}

ICTs, no matter what form they take, whether it be products, installations, tools, programmes, applications or simply content, are resulting in groundbreaking changes and transformations of a social, cultural, economic and technological nature. It is quite a strategically important factor for states, companies and, above all, each individual, and especially (but certainly not just) young people to learn to use these ICTs and to become «literate» in them. Young people have access to more and more information and training material beyond the classroom thanks to multimedia formats, educational software, digital television, IT networks and audiovisual content for video, etc. ICTs play a very important role in their culture, even though for many it has become trivialised with its only expression being the rather «useless» leisure pursuit of getting to the next level on the latest videogame. ICT should also be used to learn how to read "properly", how to understand things better and how to find out how to invenire - paying homage to the classic and still unprecedented contribution to Western literary theory by Horace and Quintilian: that it is better to have knowledge and to know how to apply, express and write it down. ICTs can only make an efficient contribution to this if they, to put it simply, make it easier to read «more» and better, i.e. that reading is "motivated" and supported by teachers who are adequately trained in the values of meaningful reading (Fletcher, Grimley, Greenwood, \& Parkhill, 2012, pp. 9-10). We need to support what we read with what we have seen and understood, as ICTs mean we can go beyond Horace's maxim of ut pictura poesis, which was so useful for capturing the true meaning of the mimesis and thesis of the documents (Fletcher, Grimley, Greenwood, \& Parkhill, 2012, pp. 10-11 and 14; Martines, 2012). As a whole, they improve the capacity for understanding, even for new concepts, i.e. improving the capacity for learning and understanding, and to putting them down on paper - thereby affirming communication skills and aptitudes (Brady \& Millard, 2012).

A great deal of reading takes place both in and with ICTs, and interaction and an intense cognitive relationship is formed when using them, even when «simply» playing a videogame (Hannaford, 2012); in fact, videogames are often a golden opportunity for learning and educating (Del Moral Pérez, 2014).

This is supported by hypertext and the relative texture of on-line reading - a faithful reflection of writing in and for a digital context - which is relational and firmly based in the ethereal nature of the cloud. A person can write at a particular moment and in a particular place, but what is written can be 
read, seen, heard, understood and implemented by many (or by a very large number indeed) in any place, in any way and in any manner. ICTs and, more specifically, the "cloud", mean that writings and readings can be created more quickly (instantaneously, in fact) Ipso facto; higher and further (in fact, they mean we can be anywhere) Ubiquus; with more force and in all different ways, Omnimodus; and can be used anywhere (and at any time) Omni tempore factus. It is as though the three principles in the Olympic motto Citius, Altius, Fortius («Faster, Higher, Stronger») proposed by Pierre de Frédy, Baron de Coubertin (with words borrowed from his friend, the Dominican priest Henri Didon) at the opening of the first Modern Olympiad in Athens in 1896 and which sum up perfectly the aims and goals of the athletes, had been transformed for ICT into: Ipso facto, Ubiquus, Omnimodus, Omni tempore factus.

In the same way, we can take it as a given that reading and writing is constant in the internet, no matter where you are (the technological gap in this sense is, of course, purely economic) in the West or the Far East (Tan, Abdullah, \& Saw, 2012). In fact, ICTs can help improve overall comprehension, evaluate general perspectives and raise awareness of the value of cooperation and, as a result, the essential quality of individuals and their contributions, "although only» from literary mimesis ... which is unlikely to result in capital goods or goods for consumption, neither manufactured nor «useful» tools in the short or long term ... Their contribution is deeper, more strategic (Finch, 2012). This is why writing - meant as the written word - and reading are not just about reading itself, but are also felt in oral expression and can result in education based more on dialogue which, in turn, leads to social change (Bignell, 2012).

If we want ICT to have a positive effect and we are aiming to reduce the negative effects such as trivialisation, loss or the simple «lack of compatibility» with other skills or aptitudes such as, for example, reading (see below), we have to accelerate the process whereby we make people become more literate in information technology and data because there are still different types of user: real users and potential users. The former belong to different sectors in society, while the latter to different generations. This results in an intergenerational issue, since it has been proven that the older generations are not as quick to adapt as younger ones: older generations are more conditioned by the educational system and the traditional way of producing information, whereas younger people are much more flexible and can adapt much more easily to change. Ultimately, ICT literacy and training with ICT should not simply be an undertaking limited to the specific area of the classroom, but should become a commitment within society, and we should talk about learning, or even education, in ICT in society as a whole (Carrington \& Robinson, 2009). 


\section{FROM «LABORIOUS» READING/WRITING ON EGYPTIAN «OSTRACA» TO VIRTUAL MUSEUM VISITS ...}

So far, one of the main functions associated with the school system has been to teach pupils literacy in culture via the printed word in its two different formats: reading, i.e. the capacity to extract meaning by the decoding of textual or discursive symbols, and writing, i.e. the capacity for communication via the production of these textual or discursive symbols. A literate person is someone who is described as having possession of both of these skills in codes for access to written or printed culture (knowing how to read) and having the skills to express oneself in textual/discursive language (knowing how to write). Nowadays, in many ways it remains difficult to acquire skills of knowing how to read and write, but in ancient times it was even more so. We only need to look at the image made by an Egyptian pupil on an ostracon, which has clearly been recycled (McDowell, 2004, p. 45). The drawing has quite obviously been corrected - the white line that the teacher has added is clearly visible. In Deir el-Medina, young pupils had individual tutors who taught them to read and write, and who provided them with general education.

Later on, in the $14^{\text {th }}$ century at the prestigious Sorbonne University, learning was still a process which involved a great deal of effort and discipline - take, for example, the implements required for both teacher and pupil (Figure 1).

These, of course, are simplified examples of how difficult it was in the past to acquire the skills associated with literacy. Nowadays, learning itself is just as hard, but the infrastructures, resources and methods are much better and much more "respectful». However, these "traditional» skills in literacy seem clearly insufficient against the current situation as they only offer access to a very limited part of the information available in modern society. They will become increasingly more insufficient as time goes by if we bear in mind the progression of the sheer amounts of information which is transmitted in, through, by and for ICT. As a result, we will see technological illiteracy which will very possibly be the cause of increased difficulties in accessing or being successful in the job market, and of misunderstanding and vulnerability with regard to recognising how information can be manipulated and the incapacity to use the resources offered by digital communications. A lack of IT skills in our society is, in a way, equivalent to those who could not read or write in society not so long ago. What we are dealing with here is "functional illiteracy». Higher education needs to be at the forefront of this new literacy and must adapt to provide a basis for and contribute to education in society (Courtney, 2013). 


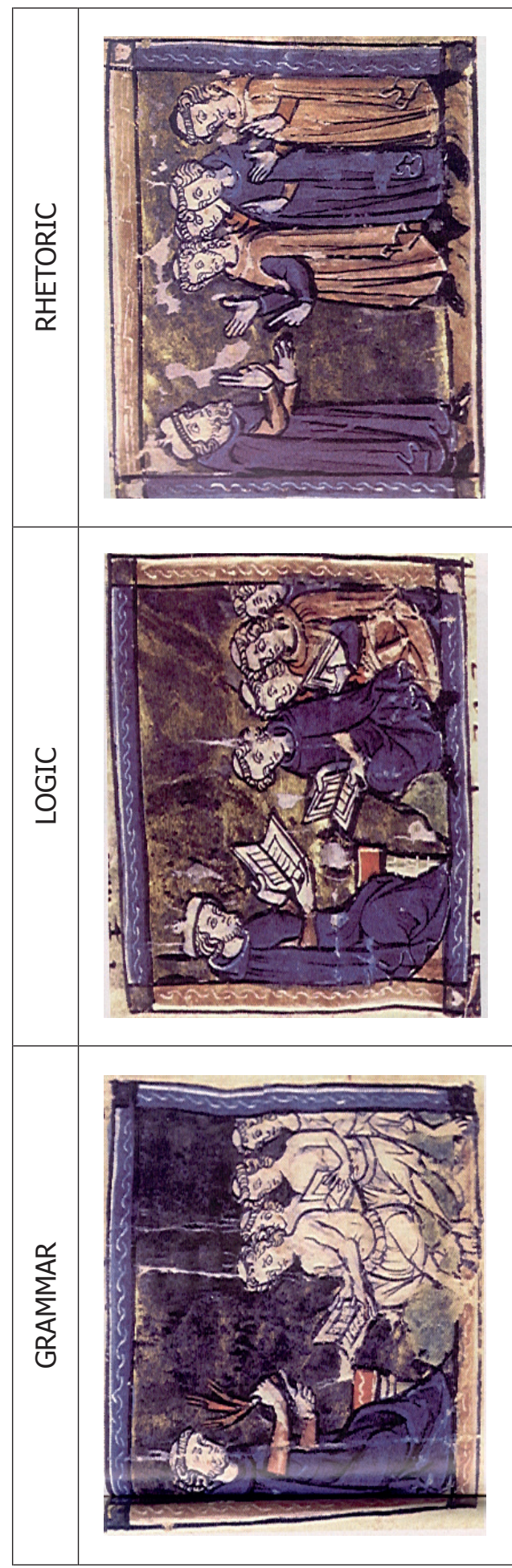

这 
Higher education needs to involve the teaching and research staff in order to optimise educational development theory in ICT (Kohoutek, 2013), although to do so would involve changing how modern universities are run in order to actually make them cooperative (Taylor, 2013). This, however, is based on a fixed, comprehensive and co-operational commitment between professors and students (Gärdebo \& Wiggberg, 2012).

Thus, we are dealing with educating for a new culture (albeit not so new anymore) which is constantly evolving. This new culture represents an educational goal - and a challenge - for the entire system. In schools, we need to implement training so that boys and girls from a young age already become qualified users of ICTs and the new culture that is developing and spreading around them. The idea is to promote and support new skills and new objectives such as mastering the technical handling of each technology from a practical point of view for both hardware and software used by each medium, and being taught a set of specific skills and knowledge that will allow them to search, select, analyse, understand, recreate and develop a critical attitude towards the truly enormous volume of information which can be accessed at the moment by ICT. It also means developing positive yet critical values and attitudes, and losing the phobia associated with some technologies and the submissive or uncritical attitude we may develop: a problem which arises not because of our access to information, but because we are not always able to select what information is relevant to us or what might be interesting in each case.

We should bear in mind that ICTs bring with them new challenges and forms of relationships, not only at the interpersonal level, but also with the objects of study and even with the type of relationship we might be able to build with what we are investigating. For example, we no longer just talk about «going to a museum» or seeing photographs of exhibit items which might appear in different magazines, on posters or postcards, etc. We now talk about "switching on" a museum, where we mean connecting our mobile devices to allow us, often in real time, to inspect and visit a museum's collection, and might even include and audio guide and hypertext or hyper-relational functions (Sucasas, 2014). Admittedly, this will not solve the old issues regarding the lack of education in art or the values of art, i.e. technology will only be able to allow us to visit the Museo del Prado (Madrid), the Museu Sant Pius V (Valencia), the Louvre (Paris), the Campidoglio (Rome), the British Museum (London) or the Vatican Museums (Vatican City) digitally; they will not instil knowledge in us or mean we can understand and appreciate the marvel that is a work of art just thanks to its being (Corazón, 2014), but they will give us all the help and provide us with all the information we need to do it ourselves. In this case, it will simply be a matter of training, or education. And this really is the heart of the matter: from this (new) literacy we need to move on up to the new digital identity. 


\section{NEW LITERACY AND DIGITAL IDENTITY: BY WAY OF A CONCLUSION}

This new education or «second literacy» in ICT, which aims to provide training and information in processes and skills, but also in new media, content and values (especially when referring to such a broad and constantly evolving topic as ICT) is by no means simple, however. It also refers to the "global» overall contribution, results and processes in different areas which, like IT, telecommunications and sound/image, have different crossover points even though they are well-defined fields with diverse applications (Lombillo, López, \& Zumeta, 2012). The diversity of these new contributions from ICT - speed, reliability, interactivity, automation of tasks, capacity of storage and handling of data, flexible access to information, communications channels, multimedia connections and reductions in costs, time and effort - also require diversity in the different skills needed to take full advantage of ICT. We need a real transformation in education which is open, participative and co-operative (Tuomi, 2013), which allows ICT to become linked "genetically» to innovation, development and learning which, in turn, are based on them (Boccomi, Kampylis, \& Punie, 2013). And this should not just be limited to the hallowed halls of universities - it also needs to interact with both primary and secondary education (De Witte \& Rogge, 2013). For this interaction to be possible, we must not ignore the current economic and social factors which have a powerful effect not only on ICT literacy, but also as far down as academic failure and quitting school. Here, in Spain, we find a perfect example of the determinant power of these factors (economic) which have a huge effect on providing effective education (Fernández-Macías, Antón, Braña, \& Muñoz, 2013).

In order to avoid the current brain drain of young people who abandon their studies even though there have never been so many technologies and tools to help them, we need strategic management at the institutional level (Austin \& Hunter, 2013; Hovdhaugen, Frølich, \& Aamodt, 2013).

Real digital literacy must not be limited to simply acquiring the skills we mentioned with regard to using ITC and its functions. We must go beyond this: we need to provide individuals with a true digital identity, a complete - and complex - development of the human condition, meant as both an increase in the potentiality of rights (and obligations) which we have as members of society, and also in the sense of improving the possibilities for all for both personal and collective development which can be understood as in the general interest and serving to protect (fundamental, social and economic) rights.

A digital identity needs to be a reinforcement of what we consider someone's own personal, group, professional and social identity (Roig, 2012). At 
the same time, it must also encompass the right to one's own image (both in the case of natural and legal persons), the right to privacy and digital reputation, and the right to «be forgotten». These rights, particularly the rights to a digital reputation and to be forgotten, are very important topics. We must bear in mind that the ubiquity and decentralisation of the "cloud" in combination with the huge social permeation of ICT and social networks and the limited control against defamation and the malicious or deliberately misleading use of information by third parties can alter or damage the image of individuals who, willingly or not, find themselves in a situation where their personal content (text or video) is shared online.

The full potential of reading, as well as individual and social values which it supports and strengthens (precisely thanks to how it transfers what is written) have been made more powerful in ICT thanks to hypertext (Calderón-Rehecho, 2012, p. 11). Not just writing, meant as the mere generation, creation or "active use» or "production/consumption" (ibid.), is a determining factor in each individual's contribution to ICT and a digital identity (one's own or in a group / social context), but reading also has a very special influence (ibid.). This is, of course, nothing new. We have already seen how reading itself has always been the companion of writing, or, as Petruci (2001) puts it very plainly: we will continue to read «while material is still being written». We would also add that material will also be written while there is still the possibility to read it, and with the technological potential of the digital word, reading will become and even more basic act - even more allencompassing, cross-sectional and recreating of the text read.

Reading along with ICTs, in general, and hypertext and multimedia/ multimodal environments and cultural changes underway in Web 2.0, specifically, take us from solid culture to liquid information, and from the static to the dynamic, flexible and global (Area \& Pessoa, 2012).

\section{REFERENCES}

Area, M., \& Pessoa, T. (2012). De lo sólido a lo líquido: las nuevas alfabetizaciones ante los cambios culturales de la web 2.0. Comunicar: Revista Cientifica de Comunicación y Educación, 38, 13-20. http://dx.doi.org/10.3916/C38-201202-01.

Austin, R., \& Hunter, B. (2013). ICT policy and implementation in education: Cases in Canada, Northern Ireland and Ireland. European Journal of Education. Research, Development and Policy, 48(1), 178-192.

Bignell, C. (2012). Talk in the primary curriculum: Seeking pupil empowerment in current curriculum approaches. Literacy, 46(1), 48-55. 
Boccomi, S., Kampylis, P., \& Punie, Y. (2013). Framing ICT-enabled innovation for learning: The case of one-to-one learning initiatives in Europe. European Journal of Education. Research, Development and Policy, 48(1), 113-130.

Brady, J., \& Millard, E. (2012). Weaving new meanings: Evaluating children's written responses to a story telling resource package. Literacy, 46(1), 17-24.

Calderón-Rehecho, A. (2012). Algunas reflexiones sobre TIC, lecura y bibliotecas. http://eprints.rclis.org/handle/10760/16901\#.T9T0SsWJR6U (consiulted 20/05/2014)

Carrington, V., \& Robinson, M. (Eds.). (2009). Digital literacies: Social learning and classroom practices. London: Sage.

Corazón, A. (2014). Ver o no ver, ésa es la cuestión. El País, 12 Abril. http://cultura. elpais.com/cultura/2014/03/11/actualidad/1394572257_003023.html.

Courtney, K. (2013). Adapting higher education through changes in academic work. Higher Education Quarterly, 67(1), 40-55.

Del Moral-Pérez, M. (Ed.). (2014). Monograph. videogames: Opportunities for learning. NAER - Journal of New Approaches in Educational Research, 3(1), 1. doi: $10.7821 /$ naer.3.1.1.

De Witte, K., \& Rogge, N. (2013). Dropout from secondary education: All's well that begins well. European Journal of Education. Research, Development and Policy, 48(1), 131-149.

Fernandez-Macías, E., Antón, J. I., Braña, F. J., \& Muñoz Del Bustillo, R. (2013). Early school-leaving in Spain: Evolution, intensity and determinants. European Journal of Education. Research, Development and Policy, 48(1), 58-78.

Finch, B. (2012). Harry Potter and «the landscape of consciousness»: Repeat home viewers' understandings about character. Literacy, 46(1), 39-47.

Fletcher, J., Grimley, M., Greenwood, J., \& Parkhill, F. (2012). Motivating and improving attitudes to reading in the final years of primary schooling in five New Zealand schools. Literacy, 46(1), 3-16.

Gärdebo, J., \& Wiggberg, M. (Eds.). (2012). Students, the university's unspent resource: Revolutionising higher education through active student participation. Uppsala: Uppsala University.

Hannaford, J. (2012). Imaginative interaction with Internet games. Literacy, 46(1), 25-32.

Hovdhaugen, E., Frølich, N., \& Aamodt, P. O. (2013). Informing institutional management: Institutional strategies and student retention. European Journal of Education. Research, Development and Policy, 48(1), 58-78.

Kohoutek, J. (2013). Three decades of implementation research in higher education: Limitations and prospects of theory development. Higher Education Quarterly, 67(1), 56-79.

Lombillo Rivero, I., López Padrón, A., \& Zumeta Izaguirre, E. (2012). Didactics of the use of ICT and traditional teaching aids in municipal higher education 
institutions. NAER - Journal of New Approaches in Educational Research, 1(1), 33-40. doi: 10.7821/naer.1.1.33-40.

López Poza, S., \& Pena Sueiro, N. (Coords.). (2014). Humanidades digitales: desafíos, logros y perspectivas de futuro. Janus. Estudios sobre el Siglo de Oro, Anexo 1. http://www.janusdigital.es/anexo.htm?id=5.

Martines, V. (2012). Enlighting with words. Text and image in Curial e Güelfa. In A. Ferrando (Coord.), Estudis lingüistics i culturals sobre Curial e Güelfa: Novella cavalleresca anònima del segle XV en llengua catalana. Linguistic and Cultural Studies on "Curial e Güelfa» a 15th Century Anonymous Chivalric Romance in Catalan, Vol. 1 (pp. 363-386). Amsterdam - Philadelphia: John Benjamins.

McDowell, A. G. (2004). La vida diaria en el antiguo Egipto. Investigación y Ciencia [ed. esp. Sientific American], Temas 37: Civilizaciones antiguas, 40a-45c.

Petruci, A. (2001). Leer por leer. In G. Cavallo \& R. Chartier (Coords.), Historia de la lectura en el mundo occidental. Madrid: Taurus.

Roig Vila, R. (2012). Spanish policies on information and communication technologies in education. REM - Researches on Education and Media, 4(2), 205-218.

Sucasas, A. L. (2014). ¿Ir al museo? ¿Encender el museo?, El País, 12 Abril. http:// cultura.elpais.com/cultura/2014/02/13/actualidad/1392294015_530976. html.

Tan, K. E., Ng Lee Yen Abdullah, M., \& Guan Saw, K. (2012). Online activities of urban Malaysian adolescents: Report of a pilot study. Literacy, 46(1), 33-39.

Taylor, M. (2013). Shared governance in the modern university. Higher Education Quarterly, 67(1), 80-94.

Tuomi, I. (2013). Open educational resources and the transformation of education. European Journal of Education. Research, Development and Policy, 48(1), 58-78.

Tusón, J. (2012). El nacimiento de las escrituras y los orígenes de la reflexión lingüística. In J. L. Mendivil Giró \& M. C. Horno Chéliz (Coords.), La sabiduría de Mnemósine. Ensayos de historia de la lingüistica (pp. 75-86). Zaragoza: Prensas Universitarias de Zaragoza.

Tusón, Je. (2013). La creatividad literaria: límites y libertades. Textos de Didáctica de la Lengua y la Literatura, 63, 83-90.

Watson, P. (2010). Ideas. Historia interlectual de la Humanidad. Barcelona: Crítica. 


\section{RiassunTO}

Questo articolo intende analizzare le strategie chiave nel rapporto tra lettura e scrittura nell'ambito delle TIC $e$, di conseguenza, intende mostrare l'importanza di sostenere l'alfabetizzazione in questo settore affinché listruzione nel suo complesso (scuole primarie, secondarie e università) sia guidata al pieno utilizzo delle TIC in modo da sviluppare le opportunità che esse sono in grado di offrire. Le TIC sono in grado cioè di contribuire a migliorare la comprensione reciproca aumentando la consapevolezza del valore della cooperazione e, di conseguenza, sono capaci di far emergere il contributo dei singoli individui alla comunicazione sociale. Questi elementi sono di vasta portata e di rilevanza strategica ai fini educativi e formativi. I vantaggi dell'applicazione delle TIC nella lettura e nella scrittura sono inoltre avvertiti anche nell'espressione orale poiché rinforzano, come risultato, un orientamento educativo maggiormente basato sul dialogo: tutto ciò conduce, di conseguenza, ad un cambiamento sociale.

Parole chiave: Didattica della lettura e della scrittura, Identità digitale, Organizzazione scolastica, Storia della cultura, TIC. 